\title{
Ceramide-induced apoptosis occurs independently of caspases and is decreased by leupeptin
}

\author{
Marc-Antoine Belaud-Rotureau ${ }^{1,2}$, \\ Francis Lacombe ${ }^{1,3}$, Françoise Durrieu², \\ Jean-Philippe Vial ${ }^{1,2}$, Laurent Lacoste ${ }^{1}$, Philippe Bernard ${ }^{1,2}$ \\ and Francis Belloc ${ }^{*, 1,2}$ \\ ${ }^{1}$ Laboratoire d'Hématologie, Hôpital Haut-Levêque, 33604 Pessac, France \\ ${ }^{2}$ Laboratoire Universitaire d'Hématologie, Université Victor Segalen, 33076 \\ Bordeaux, France \\ ${ }^{3}$ CNRS-UMR 5540, Université de Bordeaux II, 33000 Bordeaux, France \\ * corresponding author: F. Belloc, Laboratoire de Cytométrie en Flux, \\ Hématologie, Hôpital Haut-Levêque, 33604 Pessac Cedex, France. \\ tel: (33) 556556565 ext. 33711; fax: 556556845.
}

Received 18.1.99; revised 26.5.99; accepted 9.6.99 Edited by G. Salvesen

\begin{abstract}
Caspase activation is currently proposed as a common feature of apoptosis. However, although the apoptotic events triggered by Fas ligation are well documented, the terminal effectors of the ceramide-induced pathway are not completely identified. In this work, we found that C2-ceramide (Cer)induced apoptosis was antagonised by leupeptin while Fastriggered cell death occurred in the presence of this protease inhibitor. Nevertheless, this Cer-induced apoptosis could not be attributed to chymotrypsin, calpain or proteasome activation. In addition, the caspase inhibitor Z-VAD-fmk suppressed Fas-triggered death but did not prevent ceramide-induced apoptosis. In MCF7, a caspase-3-deficient cell line, Cer has been found to induce cell death whereas an anti-Fas IgM (7C11) treatment was inefficient. Moreover, Cer induced apoptosis without DEVDase activation in U937 cell line. Finally, Cer induced an intracytoplasmic calcium release while Fas ligation remained without effect. These results are consistent with the notion that Cer acts, at least in part, independently of Fas signalling, and sheds light on a new caspase 3-free apoptotic pathway triggered by ceramide.
\end{abstract}

Keywords: apoptosis; ceramide; caspase; calpain

Abbreviations: 7C11, Fas agonists IgM antibody; Calp, calpeptin; Cer, C2-ceramide; DTT, dithiothreitol; EDTA, ethylenediaminetetraacetic acid; FADD, Fas-associating protein with death domain; HEPES, hydroxyethylpiperazineethanesulfonic acid; MG-132, carbobenzoxy-L-leucyl-L-leucyl-L-leucinal; PARP, poly(ADP-ribose) polymerase; PBS, phosphate buffered saline; SDS, sodium dodecyl sulphate; TPCK $\mathrm{N}^{\alpha}$-tosyl-Phe chloromethylketone; UV, ultra-violet; Z-VAD-fmk, N-benzyloxycarbonyl-Val-Ala-Asp-fluoromethylketone

\section{Introduction}

Apoptosis is a controlled form of cell suicide that can be triggered by a variety of internal or external signals., ${ }^{1,2}$ Ceramide has emerged as a potentially important mediator involved in the effect of a number of natural or pharmacological agents on cell growth, viability, and differentiation. ${ }^{3,4}$ This lipid second messenger is generated from sphingomyelin by the activation of a neutral and/or an acidic sphingomyelinase. Agonists of the sphingomyelin-ceramide pathway include cytokines or growth factors such as tumour necrosis factor $\alpha,{ }^{5}$ interleukin-1- $\beta,{ }^{6} \gamma$-interferon, ${ }^{7}$ nerve growth factor, ${ }^{8}$ and stress-inducing agents such as $U^{9}$ or ionising radiation, ${ }^{10,11}$ and antileukemic agents such as daunorubicin. ${ }^{12-14}$ The observation that cell-permeant ceramides could mimic the biological effects of most sphingomyelin-ceramide cycle agonists has provided significant weight to the role of ceramide in signal transduction. Ceramide has been shown to exert a wide range of biological effects, depending on the cellular model, including in particular apoptosis in many cellular models such as leukemic U937 ${ }^{5}$ and lymphoblastoid $^{15}$ and endothelial cells. ${ }^{10}$ Ceramide has been described to activate stress-activated protein kinases (SAPK/c-Jun kinase), which may be closely related to ceramide-induced apoptosis in $U 937$ and in endothelial cells. ${ }^{9}$ In addition, during apoptosis, ceramide has been shown to activate transcription factors such as NF- $\kappa B^{16}$ and AP-1. ${ }^{17}$ Nevertheless, the terminal effectors of the sphingomyelin-ceramide apoptosis pathway remain elusive.

Recent studies have demonstrated that specific protease activation is a critical element of the apoptotic process. In most systems described to date, the proteases implicated are members of a cysteine protease family which share an absolute requirement for aspartic acid in the $\mathrm{P} 1$ position of proteolytic substrates. ${ }^{18-20}$ The twelve described members of the mammalian family of these proteases, which are present as inactive precursors in resting cells, have been termed caspases (for cysteinyl aspartate-specific proteinase). ${ }^{21}$ During apoptosis, these zymogenes are cleaved at Asp-X sites thus generating two subunits, which together constitute the active protease. Activation of effector caspases, such as caspase 3 , which hydrolyse target proteins exhibiting a DEVD sequence, is considered as the common event initiated by the multiple stimuli that induce apoptosis.

Fas (APO-1) is a 45-kD membrane receptor which, when engaged by Fas ligand or anti-Fas antibody, triggers programmed cell death. ${ }^{22}$ The death pathway initiated by Fas activation is now well documented and involves a series of death-inducing molecules. FADD (Fas-associating protein with death domain) is recruited to Fas upon its engagement, ${ }^{23,24}$ leading to the activation of procaspase $^{8,25-27}$ followed by activation of other caspases and ending by caspase $3 .^{28}$ 
Shu-Ching et al, have shown that Fas-mediated and ceramide-induced death pathways are not sensitive to the same inhibitors ${ }^{29}$ and conclude that ceramide is not the mediator of Fas- initiated apoptosis. However, the role of caspase as a terminal effector in the ceramide-induced pathway of apoptosis remains to be elucidated. Therefore, we investigated Fas-mediated and Cer-induced apoptosis in two human cell lines: the U937 leukemic cell line and the MCF7 caspase 3 deficient cell line.

\section{Results}

\section{Ceramide induces apoptosis and not necrosis in U937}

Figure 1 shows the effect of $\mathrm{Cer}$ and $\mathrm{H}_{2} \mathrm{O}_{2}$ on U937 cells. The cells were double stained with both the cell permeant acridine orange and the cell impermeant propidium iodide nucleic acid probes. After Cer treatment (Figure 1A and B), cells with green fluorescent nuclei (due to the binding of acridine orange to DNA), exhibiting characteristic features of apoptotosis such as nuclear fragmentation and condensation were observed besides remaining intact cells (Figure 1A). The cytoplasm of non-permeabilised cells fluoresced in red due to the binding of
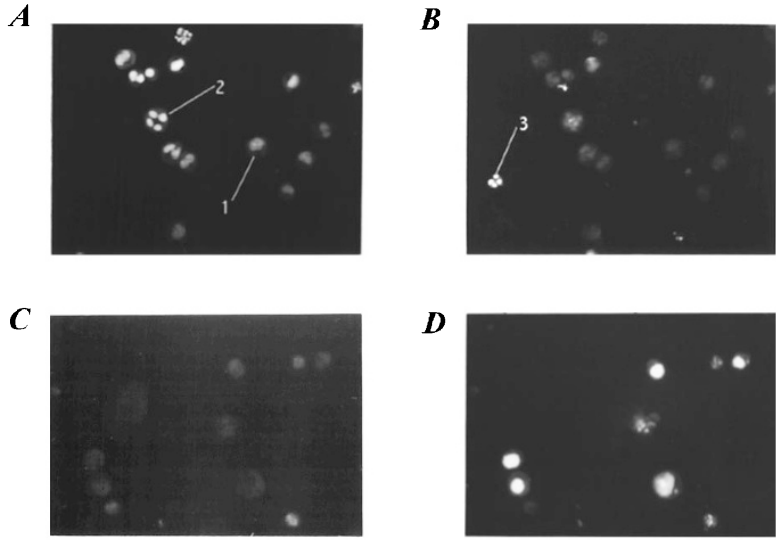

\section{$\boldsymbol{E}$}

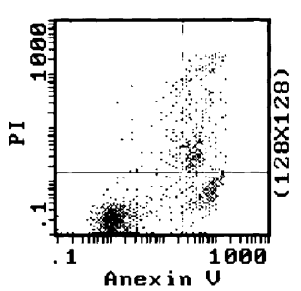

acridine orange on RNA (Figure 1B). Conversely, when the cells were treated by high concentrations of $\mathrm{H}_{2} \mathrm{O}_{2}$ (Figure $1 \mathrm{C}$ and $\mathrm{D}$ ), the nuclei were large, diffuse and brightly red fluorescent suggesting that these cells were permeable to propidium iodide and thus were necrotic cells (Figure 1D). Some red fluorescent nuclei were also observed in Figure 1B but they always were also fractionated nuclei and thus very late stages of apoptosis (secondary necrosis). These results were confirmed by analysis of phosphatidylserine exposure and permeability to propidium iodide by flow cytometry (Figure 1E and F). When treated with Cer, some U937 cells became brightly positive for annexin $\mathrm{V}$ binding but remained imperme-

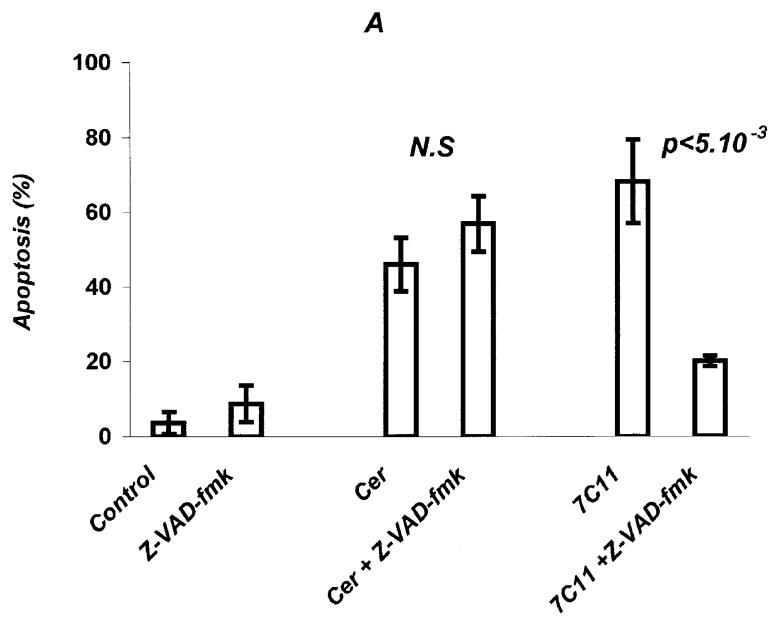

B

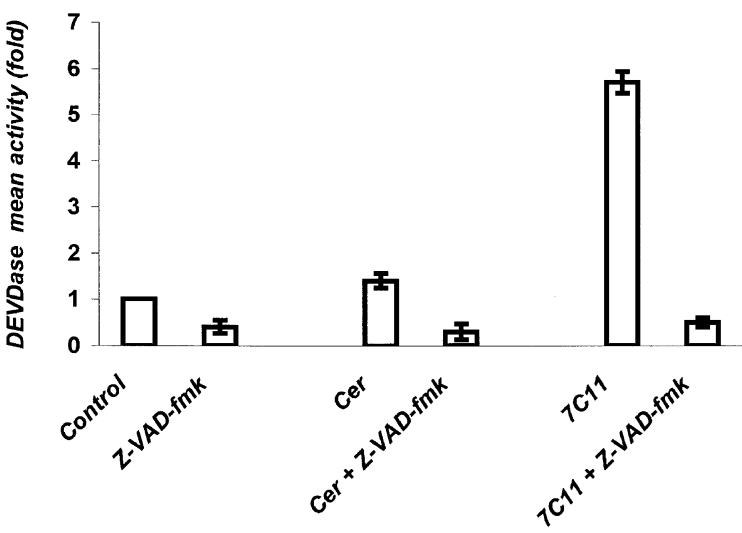

Figure 2 Effect of caspase inhibition on the apoptotic events induced by Cer of Fas ligation. U937 cells were preincubated in the presence or the absence of Z-VAD-fmk for $1 \mathrm{~h}$ when indicated and either $50 \mu \mathrm{M}$ Cer, or $0.1 \mu \mathrm{g} / \mathrm{ml}$ antiFas IgM (7C11) were added for $18 \mathrm{~h}$. (A) the apoptotic cells with condensed chromatin and/or fractionated nucleus were identified by fluorescence microscopy after acridine orange staining. The percentage of apoptotic cells was plotted for each treatment group (mean \pm S.D. from three separate experiments). (B) The DEVDase activity was measured as described in Materials and Methods using a fluorogenic substrate and spectrofluorimetry. A control without apoptosis inducer was processed for each experiment. The relative caspase activity (activity of the sample/activity of the untreated control) was plotted for each treatment group (mean \pm S.D. from three separate experiments)
Figure 1 Ceramide induces apoptosis in U937 cells. U937 cells were treated with either $50 \mu \mathrm{M} \operatorname{Cer}(\mathbf{A}, \mathbf{B}, \mathbf{E})$ or $1 \mathrm{mM} \mathrm{H}_{2} \mathrm{O}_{2}(\mathbf{C}, \mathbf{D}, \mathbf{F})$ for $18 \mathrm{~h}$. The cells were then stained with $3 \mu \mathrm{g} / \mathrm{ml}$ acridine orange and $3 \mu \mathrm{g} / \mathrm{ml}$ propidium iodide $(\mathrm{PI})$ and analyzed by fluorescence microscopy $(\times 100)$ through green $(\mathbf{A}, \mathbf{C})$ or red (B, D) emission band-pass filters. Arrow 1 points to an intact cell, arrow 2 to an apoptototic cell and arrow 3 to a cell in late apoptosis. The cells were also stained with FITC-Annexin V and PI and analyzed by flow cytometry (E, F). Green fluorescence (Annexin $V$ ) is plotted on the $x$ axis and red fluorescence (PI) on the y axis 
able to propidium iodide (Figure $1 \mathrm{E}$ ), while when treated with $\mathrm{H}_{2} \mathrm{O}_{2}$, most $\mathrm{U} 937$ cells exhibited a red fluorescence concomitant with a partial accessibility of phosphatidylserines to annexin V (Figure 1F). It was thus conclude that, unlike $\mathrm{H}_{2} \mathrm{O}_{2}$, ceramide induced apoptosis but not necrosis in U937 cells.

\section{DEVD specific caspase activation is not necessary for Cer-induced apoptosis}

The apoptosis potential was evaluated in $\mathrm{U} 937$ cells in response to either Cer or Fas ligation. Both Cer and $7 C 11$ produced a significant amount of apoptosis cells after overnight incubation. This was found at the nucleus level by analyzing chromatin condensation and/or nucleus fragmentation (Figure $2 \mathrm{~A}$ ), and at the mitochondrial level by measuring membrane potential with DiOC6(3) and flow cytometry (data not shown). When the cells were pretreated for $1 \mathrm{~h}$ with $\mathrm{Z}$ VAD-fmk, a wide spectrum caspase inhibitor, Fas-driven apoptosis was significantly reduced while Cer-induced apoptosis was not inhibited. This suggests that at least one VAD inhibitable caspase necessary for Fas apoptosis is not involved in Cer apoptosis. The DEVDase activity was

\section{A}

\section{U937 MCF7 Jurkat}

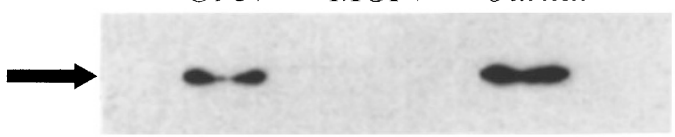

B
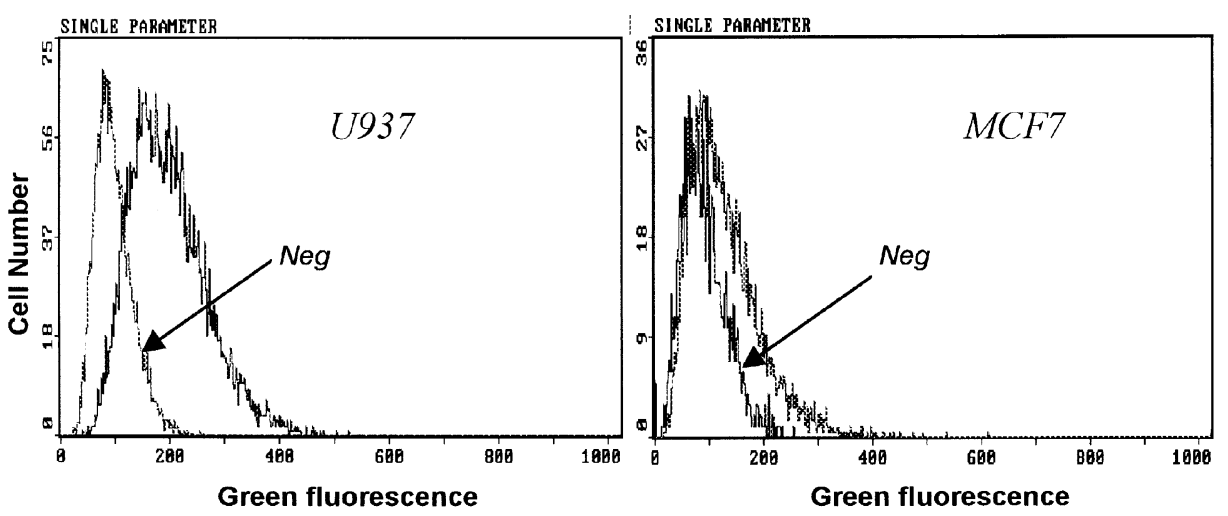

C

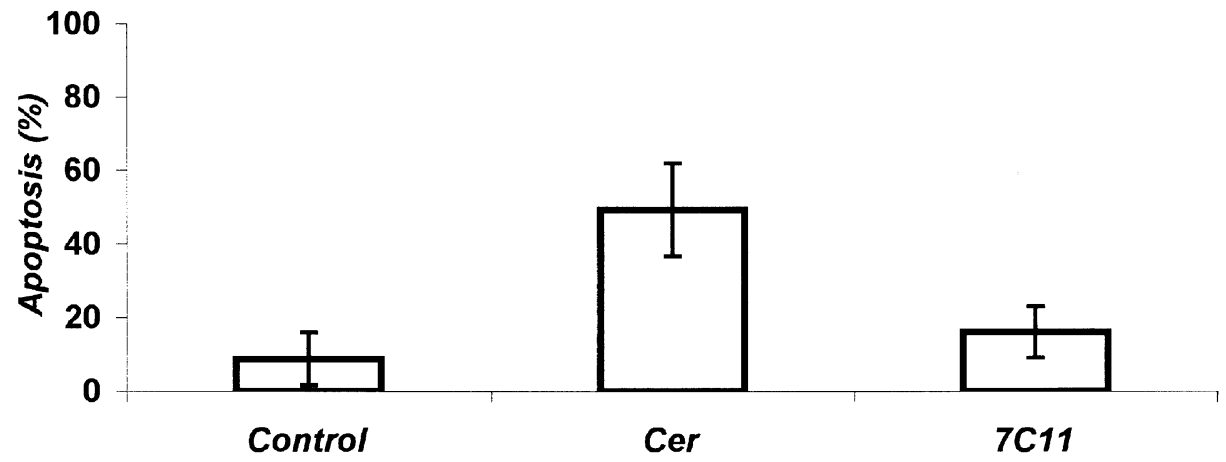

Figure 3 (A) Procaspase 3 expression in U937, MCF7 and Jurkat cells. Untreated U937, MCF7 and Jurkat cells were analyzed for their procaspase 3 content by Western blot using an anti-CPP32/Caspase-3 antibody (total protein content from a lysate of $5 \times 10^{5} \mathrm{cells}$ ). The arrow indicates the $32 \mathrm{kD}$ procaspase. (B) Fas expression in U937 and MCF7 cells. U937 and MCF7 cells were labelled with FITC-coupled anti-CD95 IgG and analyzed by flow cytometry. The fluorescence histograms are shown. Neg indicate histograms obtained with an isotypic unrelated FITC-coupled IgG as a negative control. (C) Effect of Cer and Fas ligation on MCF7 cell apoptosis. MCF7 cells were treated for $18 \mathrm{~h}$ with either $50 \mu \mathrm{M}$ Cer or $0.1 \mu \mathrm{g} / \mathrm{ml} 7 \mathrm{C} 11$. The cells were then trypsinised, and analyzed for apoptosis at the nucleus level with acridine orange and fluorescence microscopy. The results show the percentage of apoptotic cells for each treatment group (mean \pm S.D. from three separate experiments) 
measured using a fluorogenic substrate (Figure 2B) after either Cer or 7C11 treatment. While 7C11 induced a sixfold increase in DEVDase activity, the latter was only 1.5-fold that of the control after Cer treatment. This activity was completely abolished in all the Z-VAD-fmk treated samples. Thus, no activation of DEVDase occurred in Cer-treated U937 cells, which could account for the lack of effect of Z-VAD-fmk on apoptosis. Because caspase 3 constitutes the major part of DEVDase and because it is thought to be the final caspase effector in apoptosis, we checked whether caspase 3 activity was necessary for Cer apoptosis induction.

\section{Caspase 3 is necessary for Fas-mediated but not for Cer-induced apoptosis}

MCF7, a human breast carcinoma cell line, has been previously described as deficient in procaspase $3 .^{30,31}$ It was thus interesting, to verify whether MCF7 responded differently to Cer and $7 \mathrm{C} 11$ treatments. Figure $3 \mathrm{~A}$ confirms that no procaspase protein could be detected in MCF7 cells while it could easily be revealed in U937 and Jurkat cells. Fas was expressed on the MCF7 membrane at a level which was comparable with its expression in U937 cells as measured by immuno-fluorescent labelling and flow cytometry analysis (Figure 3B). However, while a consistent level of apoptotic cells was observed in response to Cer treatment, $7 \mathrm{C} 11$ was without effect on apoptosis induction (Figure $3 \mathrm{C}$ ). These results confirm that caspase 3 is not involved in the Cer proapoptotic effect but is essential for Fas-mediated apoptosis.

\section{Cer-induced apoptosis occurs through activation of a leupeptin-sensitive protease}

Because poly(ADP-ribose) polymerase (PARP) is one of the natural in-situ substrates for DEVD-specific caspases, it was interesting to analyse PARP cleavage in the cells after Cer and $7 \mathrm{C} 11$ treatment. After $18 \mathrm{~h}$, the latter resulted in an almost complete cleavage of PARP (Figure 4, lane 3). It may be noticed that Z-VAD-fmk only partly inhibited PARP cleavage after Fas ligation (Figure 4, lane 4 compared to

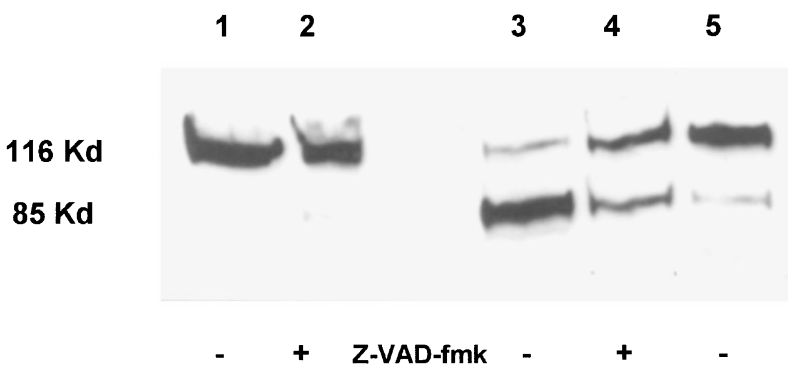

Figure 4 Effects of Cer, Fas ligation and caspase inhibitor on the PARP cleavage. U937 cells were preincubated in the presence or the absence of ZVAD-fmk for $1 \mathrm{~h}$ when indicated and either $50 \mu \mathrm{M}$ Cer, or $0.1 \mu \mathrm{g} / \mathrm{ml} 7 \mathrm{C} 11$ were added for $18 \mathrm{~h}$. The cell extracts were then processed for SDS-PAGE and Western blot using an anti-PARP monoclonal antibody as a probe. The positions of the $116 \mathrm{kD}$ intact PARP and of the $85 \mathrm{kD}$ cleaved PARP fragment are indicated. Lane 1, untreated control; lane 2, Z-VAD-fmk treated cells; lane 3, 7C11 treated cells; lane 4, Z-VAD-fmk and 7C11 treated cells; lane 5, Cer treated cells lane 3) while apoptosis and DEVDase activity were completely abolished (Figure 2). When the cells were treated by Cer, a faint cleaved fragment of PARP was detected (Figure 4, lane 5), due either to the low activation of DEVDspecific caspases (Figure 2) or to another protease.

To characterise such an hypothetical protease, several protease inhibitors were assayed for their ability to inhibit Cer-induced apoptosis. One of them, leupeptin, a wide spectrum inhibitor, was found to strongly inhibit Cerinduced apoptosis, but remained without effect on Fasmediated apoptosis (Figure 5A), thus suggesting that Cerinduced apoptosis occurs through the activation of an unknown leupeptin-inhibitable protease.

A Western-blot analysis showed that after Cer activation the PARP cleavage was not observed in MCF7 cells, which were deficient in caspase 3 (data not shown). Moreover, in U937, Cer activation induced a faint PARP cleavage which was not inhibited by leupeptin (data not shown). Therefore, the PARP cleavage observed in Cer-treated U937 cells

$\boldsymbol{A}$
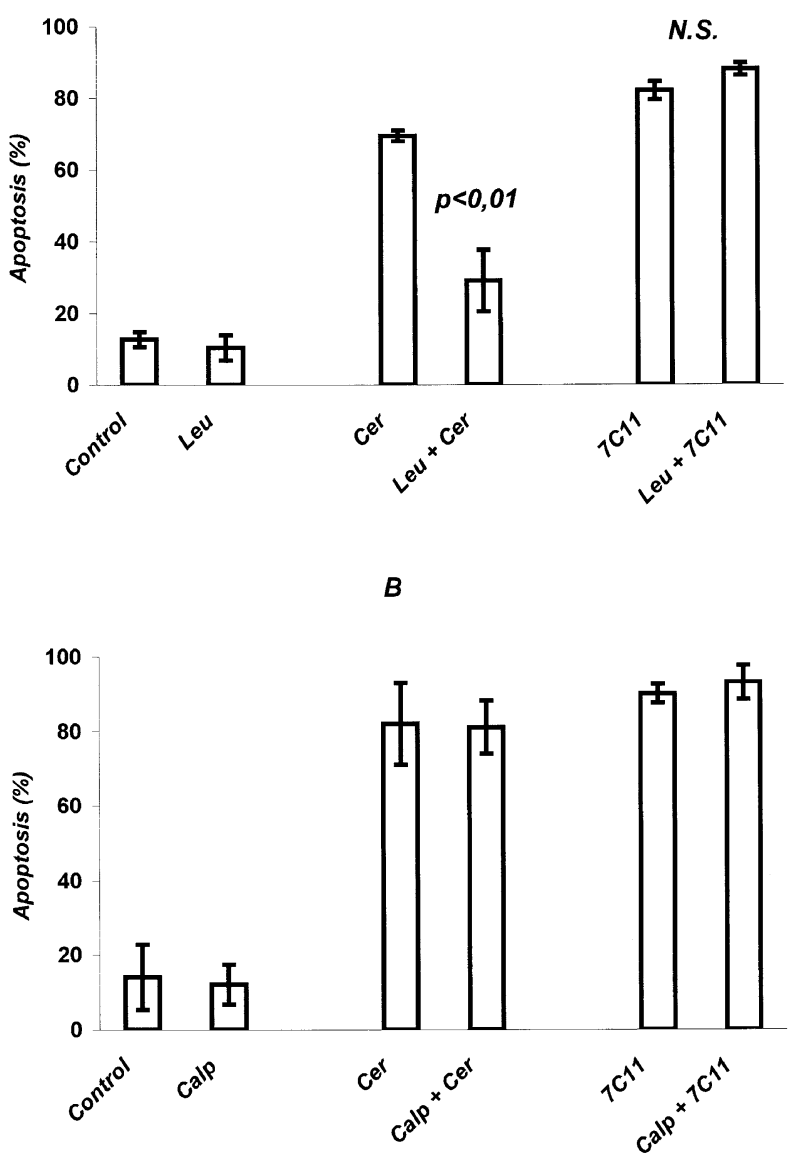

Figure 5 Effect of protease inhibitors on the apoptosis induced by Cer or Fas ligation. U937 cells were pretreated for $1 \mathrm{~h}$ with either $20 \mu \mathrm{M}$ leupeptin $(\mathbf{A})$ or $100 \mu \mathrm{M}$ calpeptin (B). Either $50 \mu \mathrm{M}$ Cer, or $0.1 \mu \mathrm{g} / \mathrm{ml} 7 \mathrm{C} 11$ were then added for $18 \mathrm{~h}$. Apoptosis was determined by fluorescence microscopy after acridine orange staining. A control without apoptosis inducer was processed for each experiment. The percentage of apoptotic cells was plotted for each treatment group (mean \pm S.D. from three separate experiments) 
cannot be attributed to the Cer-activated-leupeptin-inhibitable protease, so the low DEVDase activation observed in Figure 2 in these conditions could be sufficient to explain the cleavage observed.

Leupeptin has been previously reported to inhibit calpain. $^{32}$ Thus a specific calpain inhibitor, calpeptin (calp), was also tested but was found to be without effect on both Cer and 7C11-induced apoptosis (Figure 5B). Similarly, TPCK, an inhibitor of chymotrypsin was found to have no effect, while MG-132, a specific inhibitor of proteasome ${ }^{33}$ induced apoptosis by itself (data not shown).

\section{Cer induces a release of cytoplasmic $\mathrm{Ca}^{2+}$ while 7C11 does not}

We used flow cytometry to monitor the release of $\mathrm{Ca}^{2+}$ in the cytoplasm of U937 cells after Cer or $7 \mathrm{C} 11$ treatment. It was found (Figure 6) that Cer induced a release of $\mathrm{Ca}^{2+}$ in a dosedependent way. The higher the Cer concentration, the faster

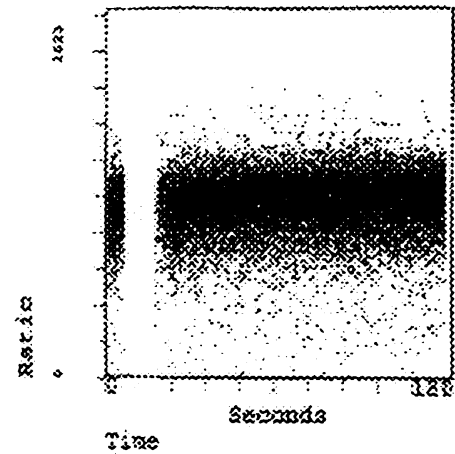

A

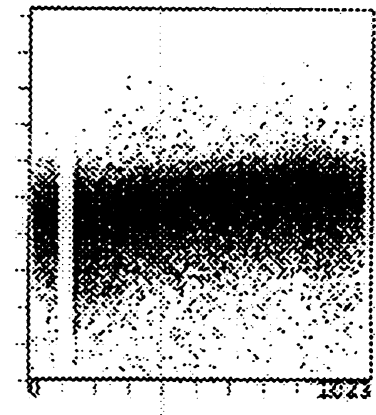

$T 2386$

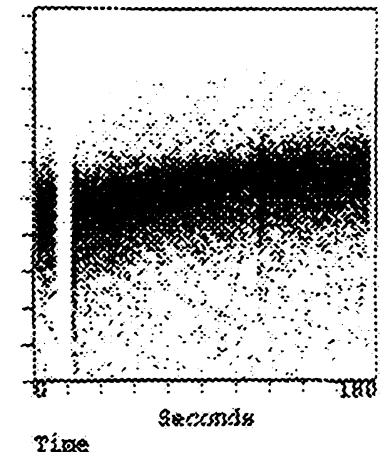

B

C

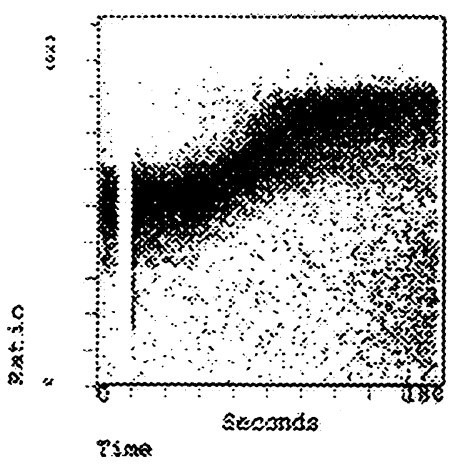

D

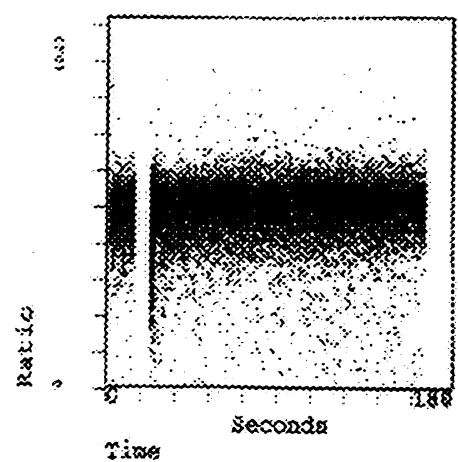

$\boldsymbol{F}$

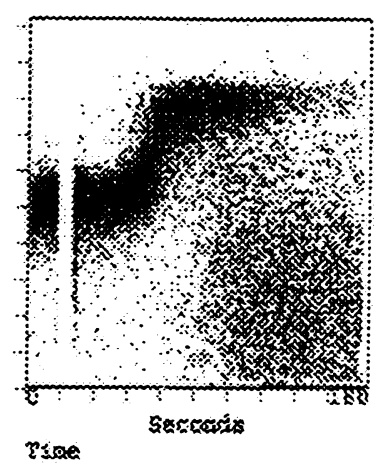

$E$

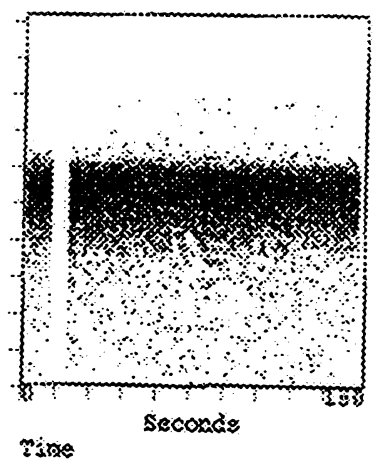

G

Figure 6 Comparative effects of Cer and Fas ligation on the cytoplasmic $\mathrm{Ca}^{++}$release in U937 cells. U937 cells were loaded with Indo 1 -AM (4.5 $\mu \mathrm{M}$ ) for 90 min $37^{\circ} \mathrm{C}$. The indicated amount of inducer was then added in an aliquot and the fluorescence ratio $410 / 480 \mathrm{~nm}$ was measured on a cell-by-cell basis using flow cytometry. The analysis was performed at a rate of 200 events/second for $3 \mathrm{~min}$. The ratio was plotted as a function of the time after injection of 0 (A), 50 (B), 75 (C), 100 (D), or 200 (E) $\mu \mathrm{M}$ Cer. Two concentrations 0.1 (F) and $1 \mu \mathrm{g} / \mathrm{ml}(\mathbf{G})$ of 7 C11 were also assayed. The empty region in the kinetics corresponded to the addition of the inducer 
the release. A 2-4-fold increase in Cer concentration was accompanied by a steep increase in cytoplasmic $\mathrm{Ca}^{2+}$, and was followed by a cell toxicity which appeared as a low $\mathrm{Ca}^{2+}$ containing population on Figure 6D and E. On the contrary, Fas ligation was not followed by a short-term change in cytoplasmic $\mathrm{Ca}^{2+}$ content, even when the $7 \mathrm{C} 11$ concentration was increased tenfold (Figure 6F and $\mathrm{G}$ ). This experiment strongly suggests that Cer-induced and Fas-driven apoptosis occur through different cytoplasmic events which lead to similar nuclear and mitochondrial effects.

\section{Discussion}

When caspase 3 was identified as the mammalian analogue of the $C$. elegans ced-3 gene product, ${ }^{34}$ it was suggested that this protease could be a confluent effector for all the apoptosis pathways. A caspase 3 substrate was then described in mice which, after cleavage, released an active DNase responsible for the typical internucleosomal fragmentation of chromatin during apoptosis. ${ }^{35}$ However, mice with an homozygous deletion in the $C A S P$-3 gene were able to complete a normal development of all organs except the brain, ${ }^{36}$ suggesting that alternative apoptosis pathways could be effective independently of caspase 3 .

We investigated in this study the role of caspases in Cerinduced and Fas-mediated apoptotic pathways in U937 cells, and confirm that both pathways result in chromatin condensation and nuclei fragmentation as observed by fluorescence microscopy. However, Z-VAD-fmk, a potent inhibitor of caspase activation, was found to be without effect on Cer-induced apoptosis, while it completely abolished Fas-mediated nuclei fragmentation. Moreover, Cer-induced apoptosis was accompanied only by a very faint activation of DEVD-specific caspases. Because caspase 3 is considered to be the main DEVD-specific caspase, it was interesting to verify if caspase 3 was essential for Cer-induced apoptosis. We addressed this question with the caspase-3 deficient MCF-7 cell line which has been described as having a functional deletion of the CASP-3 gene. ${ }^{30}$ We found that MCF-7 cells were competent to complete nuclear apoptosis in response to Cer, but were not so in response to the Fas agonist antibody $7 \mathrm{C} 11$ although they expressed Fas. This strongly supports the idea that caspase 3 is not necessary for Cerinduced apoptosis. It has been previously described in MCF-7 cells that caspase 3 is not essential for tumour necrosis factor- or staurosporine-induced cell death, but is required for DNA fragmentation and typical apoptotic morphological changes. ${ }^{30}$ Assuming that chromatin condensation and nuclei fragmentation result from DNA cleavage, ${ }^{37}$ it is probable that caspase 3 is not essential for DNA fragmentation in response to Cer treatment.

We have also shown that Cer-induced apoptosis resulted only in a minimal PARP cleavage, while almost all the PARP was cleaved after Fas ligation in U937 cells. It is possible that the very low DEVDase activation observed in Figure 2 was sufficient to partially cleave PARP (Figure 4 and data not shown). This would be sufficient to complete as much apoptosis as with Fas ligation. However, no PARP cleavage at all was observed in MCF7 cells in response to
Cer, while a significant amount of apoptotic nuclei was detected. This weakens the claim that PARP cleavage is a universal marker for apoptosis and disagrees with previous results where PARP cleavage and Z-VAD-fmk inhibition of cell death were described in MCF7 cells, in the absence of caspase 3 , after tumour necrosis factor $\alpha /$ cycloheximide or staurosporine treatment. ${ }^{31}$ This further suggests that Cerinduced apoptosis uses a specific pathway independently of DEVD-specific caspase activation, which would be essential for Fas-, tumour necrosis factor $\alpha$ - and staurosporine-mediated apoptosis.

Such an hypothesis is reinforced by our finding that Cerinduced apoptosis was inhibited by leupeptin, while Fasmediated apoptosis was insensitive to this protease inhibitor. Since leupeptin was without effect on DEVDspecific caspase, ${ }^{34}$ this suggests that Cer treatment might activate another protease or protease family which would be sufficient to complete apoptosis in the nucleus. The protease, which was not inhibited by the calpain inhibitor calpeptin, was not responsible for the partial PARP cleavage which was observed after Cer treatment in U937 cells, suggesting that activation of this protease does not necessarily exclude a partial activation of caspase 3 when possible. This ceramide-activated protease resembles the mitochondrial apoptosis inducing factor (AIF) which has been recently characterised. ${ }^{38}$ However, it is not known if AIF is inhibited by leupeptin.

Finally, we show that Cer treatment is followed by a short-term, dose-dependant release of $\mathrm{Ca}^{2+}$. while Fas ligation remains without effect on the cytoplasmic $\mathrm{Ca}^{2+}$ content whatever the dose. This result is also in agreement with the existence of different apoptotic pathways for Cerinduced and Fas-mediated apoptosis, although both resulted in a decreased mitochondrial membrane potential, a condensed chromatin and typical nuclear morphological changes.

\section{Material and Methods}

\section{Cells and reagents}

The experiments were performed on human monocytic U937, lymphocytic Jurkat, and MCF7 breast carcinoma cell lines. The cells were maintained in RPMI 1640 (Gibco BRL, Eragny, France) supplemented with $10 \%$ foetal calf serum, $1 \mathrm{mM}$ glutamine (Gibco BRL, Eragny, France), $10 \mathrm{mM}$ HEPES (Gibco BRL, Eragny, France), 100 units $/ \mathrm{ml}$ penicillin (Gibco BRL, Eragny, France), $50 \mu \mathrm{g} / \mathrm{ml}$ streptomycin (Gibco BRL, Eragny, France), in a humidified $5 \% \mathrm{CO}_{2}$, $37^{\circ} \mathrm{C}$ warmed incubator. Cells were incubated with several drugs. The caspase inhibitor Z-VAD-fmk (20 $\mu \mathrm{M}$, Calbiochem, Meudon, France) was added $1 \mathrm{~h}$ before inducing apoptosis with either $50 \mu \mathrm{M}$ Cer (C2Ceramide, Molecular Probes, Interchim, Montluçon, France) or $0.1 \mu \mathrm{g} /$ $\mathrm{ml}$ anti-Fas IgM (7C11, Immunotech, Marseille, France). Other protease inhibitors such as leupeptin $(20 \mu \mathrm{M}$, Sigma, St. Quentin Fallavier, France), the calpain specific inhibitor, calpeptin $(100 \mu \mathrm{M}$, Calbiochem, Meudon, France), the chymotrypsin inhibitor TPCK (10 $\mu \mathrm{M}$, Calbiochem, Meudon, France), or the proteasome inhibitor MG-132 (30 $\mu \mathrm{M}$, Calbiochem, Meudon, France) were used in the same way. All experiments were done on exponentially growing cells. 


\section{Apoptosis determination}

For all cell lines, apoptosis was determined after $18 \mathrm{~h}$ of either Cer or $7 \mathrm{C} 11$ treatment by using acridine orange and $\mathrm{DiOC}_{6}(3)$ assays. The acridine orange assay consisted in staining of cells in their culture medium with $3 \mu \mathrm{g} / \mathrm{ml}$ acridine orange and $3 \mu \mathrm{g} / \mathrm{ml}$ propidium iodide (Molecular Probes, Interchim, Montluçon, France) and fluorescence microscopic analysis. Cells with green fluorescent condensed chromatin and/or fractionated nucleus were scored as apoptotic. ${ }^{39}$ The mitochondrial potential was assayed with $\mathrm{DiOC}_{6}(3)$ Cells were incubated in culture medium for $30 \mathrm{~min}$ at $37^{\circ} \mathrm{C}$ with $100 \mathrm{ng} / \mathrm{ml}$ $\mathrm{DiOC}_{6}(3)$ (Molecular Probes Interchim, Montluçon, France) and analyzed by flow cytometry as previously described. ${ }^{39-41}$ Low mitochondrial potential cells were scored as apoptotic.

\section{Fluorogenic protease assays}

DEVDase activity was assayed as previously described. ${ }^{39}$ Briefly, cells $\left(5 \times 10^{5}\right)$ were washed in PBS and then suspended in $50 \mu \mathrm{l}$ of a $\mathrm{pH} 7.4$ buffer containing $72 \mu \mathrm{M}$ Ac-DEVD aminomethylcoumarin (UBI, Euromedex, France). The cells were incubated for $10 \mathrm{~min}$ at $37^{\circ} \mathrm{C}$ and then centrifuged for $3 \mathrm{~min}$ at 14000 r.p.m. The supernatant was diluted in $1 \mathrm{ml} \mathrm{dH_{2 }} \mathrm{O}$. Fluorescence was measured using a Jobin and Yvon spectrofluorometer $\left(\lambda_{\mathrm{exc}}=380 \mathrm{~nm}, \lambda_{\mathrm{em}}=480 \mathrm{~nm}\right)$. A blank was performed without addition of cells in the substrate buffer and its value was subtracted from all the measurements. A control without any drug treatment was processed for each experiment. The relative enzyme activity was expressed as the ratio treated sample activity/untreated control activity.

\section{Western blot analysis}

Western blots were performed as previously described. ${ }^{42}$ PARP cleavage was analyzed in $7.5 \%$ acrylamide gel and procaspase 3 expression in a $10 \%$ acrylamide gel. Antibodies used were $1 \mu \mathrm{g} / \mathrm{ml}$ anti PARP (Zymed, Clinisciences, Montrouge, France) and $2 \mu \mathrm{g} / \mathrm{ml}$ anti CPP32/Caspase-3 (clone 19, Transduction Laboratories, Interchim, Montluçon, France).

\section{Fas expression}

Fas expression was determined by direct immunolabelling on living U937 and MCF7 cells as previously described. ${ }^{42}$ Negative control were performed with an isotypic unrelated FITC-coupled IgG. The fluorescence histograms are shown in Figure 3B.

\section{Intracytoplasmic calcium release}

Intracytoplasmic calcium release was monitored by flow cytometry with the fluorescent calcium chelator Indo-1 acetoxymethyl ester (Indo-1 AM, Molecular Probes, Interchim, Montluçon, France) as previously described. ${ }^{43}$ Briefly, $3 \times 10^{5}$ U937 cells in $1 \mathrm{ml}$ of culture medium were loaded with the fluorochrome by incubating with $4.5 \mu \mathrm{M}$ Indo-1 $\mathrm{AM}$ for $90 \mathrm{~min}$ at $37^{\circ} \mathrm{C}$. The cells were analyzed by flow cytometry, the blue fluorescence was split by a long pass $450 \mathrm{~nm}$ interferential filter and the resulting fluorescences were measured through band filters of $410 \pm 10$ and $480 \pm 10 \mathrm{~nm}$ respectively. The ratio of $410 / 480$ fluorescences was calculated on a cell by cell basis by the cytometer and plotted as a function of time. The vector (ethanol), Cer $(50$ to $200 \mu \mathrm{M})$ or $7 \mathrm{C} 11(0.1$ and $1 \mu \mathrm{g} / \mathrm{ml})$ solution were added after $15 \mathrm{~s}$ of analysis and the analysis was prolonged for $3 \mathrm{~min}$.

\section{Acknowledgements}

This work was supported in part by grants from the Ligue Nationale contre le Cancer and from the Association pour la Recherche sur le Cancer.

\section{References}

1. Thompson CB (1995) Apoptosis in the pathogenesis and treatment of disease. Science 267: 1456-1462

2. White $E$ (1996) Life, death, and the pursuit of apoptosis. Genes Dev. 10:1-15

3. Kolesnick RN (1991) Sphingomyelin and derivatives as cellular signals. Prog. Lipid. Res. 30: 1-38

4. Hannun YA (1996) Functions of ceramide in coordinating cellular responses to stress. Science 274: 1855-1859

5. Obeid LM, Linardic CM, Karolak LA and Hannun YA (1993) Programmed cell death induced by ceramide. Science 259: 1769-1771

6. Andrieu N, Salvayre R and Levade T (1994) Evidence against involvement of the acid lysosomal sphingomyelinase in the tumor-necrosis-factor-and interleukin1-induced sphingomyelin cycle and cell proliferation in human fibroblasts. Biochem. J 303: 341-345

7. Kim MY, Linardic C, Obeid L and Hannun Y (1991) Identification of sphingomyelin turnover as an effector mechanism for the action of tumor necrosis factor alpha and gamma-interferon. Specific role cell differentiation. J. Biol. Chem. 266:484489

8. Dobrowsky RT, Werner MH, Castellino AM, Chao MV and Hannun YA (1994) Activation of the sphingomyelin cycle through the low-affinity neurotrophin receptor. Science 265: 1596-1599

9. Verheij M, Bose R, Lin XH, Yao B, Jarvis WD, Grant S, Birrer MJ, Szabo E, Zon LI, Kyriakis JM, Haimovitz-Friedman A, Fuks Z and Kolesnick RN (1996) Requirement for ceramide-initiated SAPK/JNK signalling in stress-induced apoptosis. Nature 380: 75-79

10. Haimovitz-Friedman A, Kan CC, Ehleiter D, Persaud RS, McLoughlin M, Fuks Z and Kolesnick RN (1994) lonizing radiation acts on cellular membranes to generate ceramide and initiate apoptosis. J. Exp. Med. 180: 525-535

11. Santana P, Pena LA, Haimovitz-Friedman A, Martin S, Green D, McLoughlin M, Cordon-Cardo C, Schuchman EH, Fuks Z and Kolesnick R (1996) Acid sphingomyelinase-deficient human lymphoblasts and mice are defective in radiation-induced apoptosis. Cell 86: 189-199

12. Strum JC, Small GW, Pauig SB and Daniel LW (1994) 1-beta-DArabinofuranosylcytosine stimulates ceramide and diglyceride formation in HL-60 cells. J. Biol. Chem. 269: 15493-15497

13. Bose R, Verheij M, Haimovitz-Friedman A, Scotto K, Fuks $Z$ and Kolesnick $R$ (1995) Ceramide synthase mediates daunorubicin-induced apoptosis: an alternative mechanism for generating death signals. Cell 82: 405-414

14. Jaffrezou JP, Levade T, Bettaieb A, Andrieu N, Bezombes C, Maestre N, Vermeersch S, Rousse A and Laurent G (1996) Daunorubicin-induced apoptosis: triggering of ceramide generation through sphingomyelin hydrolysis. EMBO J. 15: 2417-2424

15. Tepper CG, Jayadev S, Liu B, Bielawska A, Wolff R, Yonehara S, Hannun YA and Seldin MF (1995) Role for ceramide as an endogenous mediator of Fas-induced cytotoxicity. Proc. Natl. Acad. Sci. USA 92: 8443-8447

16. Schutze S, Potthoff K, Machleidt T, Berkovic D, Wiegmann $K$ and Kronke $M$ (1992) TNF activates NF-kappa B by phosphatidylcholine-specific phospholipase C-induced 'acidic' sphingomyelin breakdown. Cell 71: 765-776

17. Sawai H, Okazaki T, Yamamoto H, Okano H, Takeda Y, Tashima M, Sawada H, Okuma M, Ishikura H, Umehara M and Domae N (1995) Requirement of Ap-1 for ceramide-induced apoptosis in human leukemia HL-60 cells. J. Biol. Chem. 270: $27326-27331$

18. Martin SJ and Green DR (1995) Protease activation during apoptosis: death by a thousand cuts? Cell 82: $349-352$

19. Chinnaiyan AM and Dixit VM (1996) The cell-death machine. Curr. Biol. 6:555562

20. Nicholson DW and Thornberry NA (1997) Caspases: killer proteases. Trends. Biochem. Sci. 22: 299-306

21. Alnemri ES, Livingston AJ, Nicholson DW, Salvesen G, Thornberry NA, Wong WW and Yuan J (1996) Human ICE/CED-3 protease nomenclature. Cell 87: 171

22. Nagata S (1997) Apoptosis by death factor. Cell 88: 355-365 
23. Chinnaiyan AM, O'Rourke K, Tewari M and Dixit VM (1995) FADD, a novel death domain-containing protein, interacts with the death domain of Fas and initiates apoptosis, Cell 81: 505-512

24. Boldin MP, Varfolomeev EE, Pancer Z, Mett IL, Camonis JH and Wallach D (1995) A novel protein that interacts with the death domain of Fas/APO1 contains s sequence motif related to the death domain. J. Biol. Chem. 270: 7795-7798

25. Muzio M, Chinnaiyan AM, Kischkel FC, O'Rourke K, Shevchenko A, Ni J, Scaffid C, Bretz JD, Zhang M, Gentz R, Mann M, Krammer PH, Peter ME and Dixit VM (1996) FLICE, a novel FADD-homologous ICE/CED-3-like protease, is recruited to the CD95 (Fas/APO-1) death-inducing signaling complex. Cell 85: 817-827

26. Boldin MP, Goncharov TM, Goltsev YV and Wallach D (1996) Involvement of $\mathrm{MACH}$, a novel MORT1/FADD-interacting protease, in Fas/APO-1- and TNF receptor-induced cell death. Cell 85: 803-815

27. Medema JP, Scaffidi C, Kischkel FC, Shevchenko A, Mann M, Krammer PH and Peter ME (1997) FLICE is activated by association with the CD95 death-inducing signaling complex (DISC). EMBO J. 16: 2794-2804

28. Enari M, Talanian RV, Wong WW and Nagata S (1996) Sequential activation of ICE-like and CPP32-like proteases during Fas-mediated apoptosis. Nature 380: $723-726$

29. Shu-Ching Hsu, Chia-Cheng Wu, Tien-Yau Luh, Chen-Kung Chou, Shau-Hwa Han and Ming-Zong Lai (1998) Apoptotic signal of Fas is not mediated by ceramide. Blood 91: 2658-2663

30. Jänicke RU, Ng P, Sprengart ML and Porter AG (1998a) Caspase-3 is required for DNA fragmentation and morphological changes associated with apoptosis. J. Biol. Chem. 273: 9357-9360

31. Jänicke RU, Ng P, Sprengart ML and Porter AG (1998b) Caspase-3 is required for $\alpha$-fodrin cleavage but dispensible for cleavage of other death substrates in apoptosis. J. Biol. Chem. 273: 15540-15545

32. Tsujinaka T, Kajiwara Y, Kambayashi J, Sakon M, Higuchi N, Tanaka T and Mori T (1988) Synthesis of a new cell penetrating calpain inhibitor (celpeptin). Biochem. Biophys, Res. Commun. 153: 1201-1208

33. Hirsch T, Dallaporta B, Zamzami N, Susin SA, Ravagnan L, Marzo I, Brenner C and Kroemer G (1998) Proteasome activation occurs at an early, premitochondrial step of thymocyte apoptosis. J. Immunol, 161: 35-40
34. Nicholson DW, Ali A, Thornberry NA, Vaillancourt JP, Ding CK, Gallant M Gareau, Y, Griffin PR, Labelle M, Lazebnik YA, Munday NA, Raju SM, Smulson ME, Yamin TT, Yu VL and Miller DK (1995) Identification and inhibition of the ICE/ CED-3 protease necessary for mammalian apoptosis. Nature 376: 37-43

35. Enari M, Sakahira H, Yokoyama H, Okawa K, Iwamatsu A and Nagata S (1998)A caspase-activated DNase that degrades DNA during apoptosis, and its inhibitor ICAD. Nature 391: 43-50

36. Kuida K, Zheng TS, Na S, Kuan C, Yang D, Karasuyama H, Rakic P and Flavell RA (1996) Decreased apoptosis in the brain and premature lethality in CPP32deficient mice. Nature 284: $368-372$

37. Sen S (1992) Programmed cell death: concept, mechanism and control. Biol. Rev. 67: $287-319$

38. Susin SA, Lorenzo HK, Zamzami N, Marzo I, Snow BE, Brothers GM, Mangion J, Jacotot E, Costantini P, Loeffler M, Larochette N, Goodlett DR, Aebersold R, Siderovski DP, Penninger JM and Kroemer G (1999) Molecular characterization of mitochondrial apotosis-inducing factor. Nature 397: 441-445

39. Durrieu F, Belloc F, Lacoste L, Dumain P, Chabrol J, Dachary-Prigent J, Morjani H, Boisseau MR, Reiffers J, Bernard P and Lacombe F (1998) Caspase activation is an early event in anthracycline-induced apoptosis and allows detection of apoptotic cells before they are ingested by phagocytes. Exp. Cell Res. 240: 165175

40. Petit X, Lecoeur H, Zorn E, Dauguet C, Mignotte B and Gougeon ML (1995) Alterations in mitochondrial structure and function are early events of dexamethasone-induced thymocyte apoptosis. J. Cell Biol. 130: 157-167

41. Vayssiere JL, PetitX, RislerY and Mignotte B (1994)Commitment to apoptosis is associated with changes in mitochondrial biogenesis and activity in cell lines conditionally immortalized with simian virus 40 . Proc. Natl. Acad. Sci. USA 91: $11752-11756$

42. Belloc F, Cotteret S, Labroille G, Schmit V, Jaloustre C, Dumain P, Durrieu F, Reiffers J, Boisseau MR, Bernard P and Lacombe F (1997) Bcr-abl translocation can occur during the induction of multidrug resistance and confers apoptosis resistance on myeloid leukemic cell lines. Cell Death Differ. 4: 806-814

43. Elliott DC and Petkoff HS (1990) Measurement of cytoplasmic free calcium in plant protoplasts. Plant Sci. 67: 125-129 